\title{
Internet Forums and the Rise of the Inventive Energy User
}

\section{Sampsa Hyysalo, Jouni K. Juntunen and Stephanie Freeman}

\begin{abstract}
While climate and energy policy voice concerns about citizen's lack of improving their houses and heating systems, some citizens by far exceed the expectations. Our research on heat pumps revealed over a hundred inventions by citizen users in Finland alone, despite the technology being in many respects uninviting to modify. Users' capacity to carry out these modifications owes much to their exchanges at userrun Internet forums, a new and proliferating type of setting. These online forums help otherwise dispersed and heterogeneous users to create a specific kind of learning space that helps some users to "grow inventive" even as the majority of users therein remain indifferent towards their specific projects. These findings open a discussion on how the actions of typically a small group of inventive users are embedded in and supported by the activities of a broader user base.
\end{abstract}

Keywords: User Innovation, Internet Forums, Renewable Energy

\section{Introduction}

Recent years have seen many attempts to include citizens as more active players in the realization of energy and climate policy. Most of these have focused on campaigns, means and measures to reduce end-user energy consumption with the thrust on how industry developed products could be made to diffuse and be used to their full potential (Nye et al., 2010). Even as many of the renewable and more local energy technologies are available offthe-shelf, the adequacy of the solutions to local problems varies with regard to building location, housing type, and activities within the house. Such variable user-requirements may spur the making of local modifications to get the best out of generic technologies in renewable energy
(Ornetzeder \& Rohracher, 2006; Seyfang \& Smith, 2007; Heiskanen et al., 2010b), as has been the case in other sectors (Fleck, 1988; Douthwaite et al., 2001; Williams et al., 2005). It is common that conditions where mass produced goods do not meet the localized needs of users result in what von Hippel calls user innovation niches that spur a significant amount of inventions by users (von Hippel, 2005; Baldwin et al., 2006). To date, energy-related user innovations have been researched in renewables such as modern biomass heating systems and solar collectors (Ornetzeder \& Rohracher, 2006), wind turbines (Jørgensen \& Karnøe, 1995; Karnøe, 1996), and in energy efficient buildings (Ornetzeder \& Rohracher, 2006).

Prompted by this background we conducted a line of research on end-users' inventive behaviours in sustainable energy 
in Finland. In this paper we examine a subset of this data related to heat pumps, which first made evident the importance of Internet-enabled and user-maintained "forums" in impelling user inventiveness in renewables. These relatively recently matured online environments appear to allow dispersed sustainable energy users to seek information and tap into each others' ideas. The forums appeared to have provided connections and efficacy that far exceeds anything that self-builders had at their disposal in the past. Most of these forums began operating after 2005 and it has taken some years for them to reach a significant scope. It is thus only now that we can take stock of whatever potential these forums may have. This state of affairs is relevant not only for our understanding of end-users' inventive behaviours with renewable energy technologies but also reveals that user-run Internet forums deserve greater attention in research on user innovation as well as on intermediation.

In such forums, people organize around products and technologies to discuss use, purchase, experiences, and community knowledge about products and producers. They also include peer support for inventions by some of their members. The dynamics between other users and inventive users holds importance for how we should view user and citizen potential in innovation. To preempt some of our findings, we argue that user-run Internet forums allow for coexistence and interchange between different peoples, competences and interests. This is conducive to some of the members "growing to become inventive", and many members gaining deeper appraisal of the technologies in question. The role of forums is emphasized in the heat pump technology we have chosen to study. Heat pumps are an unlikely area for user invention in renewables. The reasons include their technical complexity, mass production, low configurability, manufacturer disinterest in niche development, equipment integrating several specialist technology areas, and the loss of warranty and insurance coverage upon making modifications.

The contribution of the present paper is thus twofold: 1) we seek to bring to the fore the supporting role that user-run Internet forums provide for inventive citizen engagement with technology and 2) the particular implications this holds in sustainable energy technologies which is the domain of our analysis. We unite these two areas of interest with the research question:

How do user-run Internet forums support user innovation in sustainable energy technology?

Our exploration proceeds as follows. We first review research on user innovations, user communities, and Internet forums and discuss why a science and technology studies approach helps us gain new insight on the topic. We then present our data and methods and move to outline the inventions of Finnish heat pump users and the direct support they have received for realizing them. After this we examine the mechanisms that lend important indirect support for the inventive users. These findings are drawn together by discussing how they facilitate deeper engagement with technology. In the final section we draw conclusions for energy and innovation research and for related policy. We have placed in the Appendix basic information on heat pump technology and of the user forums we examine in this paper.

\section{Internet Forums and Innovation Communities in User Innovation}

Research to date has established several things about inventive users. They tend to 
get help from their peers, and this help is often vital for realizing their designs (Franke \& Shah, 2003; Jeppesen \& Molin, 2003). As in more conventional $R \& D$, inventive users are proficient in particular aspects related to technology and hence the scope of design they can master alone remains more limited than when pooling contributions to realize whole new designs (Franke \& von Hippel, 2003; Benkler, 2006). While most attention has been paid to explicitly designoriented collectivities, such as open source development (Weber, 2004; Benkler, 2006) crowdsourcing (Howe, 2009; Tapscott \& Williams, 2011) and variations of the open design movement, these are not the only areas of users' inventive actions in peer-topeer networks. In many domains innovating users are deeply embedded in communities of practice (Franke \& Shah, 2003; Baldwin et al., 2006; Hienerth, 2006; Bethwaite, 2008) or have organized design-oriented networks within them (Hienerth, 2006; Flichy, 2007; Bethwaite, 2008). It appears to be no accident that also in renewable energy the few reported user innovation success stories feature self-building groups and co-operatives (Jørgensen \& Karnøe, 1995; Ornetzeder \& Rohracher, 2006; Seyfang, 2007).

Invention prone users are, however, often geographically dispersed. Internetenabled services can boost the visibility and connectivity among potentially innovative agents. This has been observed in many online game environments (Jeppesen \& Molin, 2003; Prügl \& Schreier, 2006) and also in designing physical products, even if only some aspects of these products can be shared across the web (Sawhney et al., 2005; Jeppesen \& Frederiksen, 2006). Studies of on-line support have, however, examined relatively uniform hobbyist communities of practice, and mostly have done so quantitatively (Jeppesen \& Molin, 2003; Jeppesen \& Fredrikssen, 2006). There is some research on do-it-yourself (DIY) modifications and related blogs and forums and how they act as information repositories (Shove et al., 2007; Watson \& Shove, 2008). These suggest a link between physical innovations and virtual communities as DIY forums showcase how personal experiences and knowledge from creating physical objects are projected into the public sphere (Kuznetsov \& Paulos, 2010). Nevertheless, overall there is little research on the interrelation between user innovation and online user forums that are not set-up for innovation per se. User-run community forums are, at most, pointed to as a resource for managers to harvest or mine innovative ideas to manufacturers' benefit (Jeppesen \& Molin, 2003; Pitta \& Fowler, 2005; Franke et al., 2010).

To go deeper into the role that user-run (and not innovation-focused) Internet forums play in user inventiveness, we turn to science and technology studies concepts as a means to describe participation in complex sociotechnical formations. Our first point of departure is that design and use are not static categories, but should be examined as emerging and evolving relationships to technology (Hyysalo, 2010). People are not users, lay users or lead users per se, but rather the emergence and evolution of their usership should be examined as an accomplishment and a processual engagement between person, the practices s/he enacts and the technology s/he appropriates therein. (Helgesson \& Kjellberg, 2009). In such engagement process peers and peer networks have been observed to play a significant role, and terms such as local experts (Stewart, 2007) and user side intermediaries (Stewart \& Hyysalo, 2008) are useful in addressing the often mundane but important assistance that goes into making technologies work.

The processual view endorsed by technology studies further underscores that 
attention should be paid to more than just information exchange and the giving and receiving of help, which dominates user innovation (Franke \& Shah, 2003; Jeppesen \& Molin, 2003). Attention needs to be broadened to learning that may or may not take place in the course of the development of usership; i.e. what competences the participants build and with what effect (Shove \& Watson, 2007). When it comes to inadvertent support, concepts such as learning through legitimate peripheral participation are particularly helpful, as they help capture the often complex and multifaceted learning (and growth) process of a person moving from being a relative novice towards increasing mastery of a given practice (Lave \& Wenger, 1991; Wenger, 1998).

The pertinent questions further concern how the practices at hand are organized; in the words of Blok (2013), what is the nature of the assemblages formed. Here, Internet forums feature important diversity. Some such forums accompany a relatively homogeneous practice, such as the Finnish forum for single speed bicycles, which could well be characterized as a medium for a community of practice (Wenger, 1998). Others are tied to a joint development project(s), such as open source development initiatives, rendering the community primarily into an innovation community (Jeppesen \& Frederiksen, 2006; Freeman, 2011, Heiskanen et al., 2010). Yet other forums are diverse to the extreme, such as Suomi24, which features hundreds of discussion areas and interests. Such forums can be best characterized as boundary infrastructure (Bowker \& Star, 1999), which allows the partial co-existence of multiple social worlds. All these community/ collectivity forms entail different modes of participation and learning. The user-run Internet forums in renewables we research make possible learning through legitimate peripheral participation, but appear to be more diverse in their participants' orientations, competences and interests than, say, sporting-related communities or project-oriented innovation communities. We come to argue that this is also visible in the outcomes of the projects of their participants.

\section{Data and Methods}

Our data set consists of overviewing, sampling and content analysis of the Finnish heat pump forums, www.lampopumput. info and www.maalampofoorumi.fi, as well as 25 related interviews. The forums are actively used by heat pump users. The pages of the larger forum, lampopumput. info, had been viewed over 57 million times by January 2012, while the other forum features no page load statistics. However, a very conservative estimate based on the other forum would be in the order of several millions (if not tens of millions).

Our strategy was to first overview all major categories in the forums $(n=42)$ by going through 40-100 thread headings in each, and following 5-20 threads in detail in order to get a sense of the topics and contents in each category. We then sampled and stored typical postings in all those categories that we suspected could have been somehow relevant for user innovation. It soon became evident that in lampopumput.info most user modifications and inventions had been initiated or moved by the moderators to an "own modifications and improvements" section (hereon "DIY section"), which featured 320 discussion threads. We read through all of these threads in their entirety. The DIY section threads were between 10-15 posts per thread, but included both single posts as well as projects that featured over 300 posts. We filed all those threads, which featured user modification or behaviours that directly or 
indirectly appeared to provide support for users' inventive behaviours, and categorized them with both ex-vivo and in-vivo tags/ codes. In the ground heat pump forum the self-design projects were scattered across several categories, but could be identified nonetheless, and yielded similar analysis as with the first forum.

To gain a better idea of the inventions and discussants, and their relationship to those in the DIY section, we used the general statistics of the forum as well as manual checking of the profiles of 65 discussants active in the DIY section. The DIY discussants featured few "newbies", and mostly consisted of people whose self-designations placed them as "active participants", "experienced" or "moderators", and had between 50 and 10000 postings. We conducted $30-120$ minute long semi-structured interviews with 22 forum-active heat pump lead users and 3 firms specializing in heat pumps. Our interviews focused on the modifications that these users had made as well as their activity and interactions on the heat pump forums.

Our data analysis then proceeded through categorizing all user inventions and modifications to heat pumps in our sample. In total, we found 113 inventions or modifications that improved either the efficiency, suitability, maintenance or price of the heat pump as verified by the external evaluators we used to assess their inventiveness (reported in Hyysalo et al., 2013). We further clustered these findings into types of projects and then placed these with more general categories typical to user inventions and alterations of technology, following the naming conventions prevalent in research literature (Botero et al., 2010). We further coded the thread topics related to these forms of user inventiveness: what kinds of reactions, help, and other contributions other users volunteered to these postings/projects, and the reasons users had for their inventive actions. In parallel, we similarly content analysed the interviews with regard to inventive projects as well as the forum activities and the help the interviewed users had received. We sampled posts elsewhere in the forum for behaviours and dynamics that may support or hinder inventive users. These too were content analysed and systematically compared with regard to types of forums postings, thread topics, example solutions offered by other users, function for users and why they facilitate user innovation, and how wide a user population these activities concern. The outcome classifications of the content analysis are presented in Tables 1-4 below.

Despite our data set being extensive and multiform, it has limitations. Our interviewee sample consists of inventive users only, and hence we rely on forum posts alone in analysing other activities and participants on the forum. Notwithstanding the limitations, the present study opens the door for comparing other on line forums and types of user communities related to renewables.

\section{User Inventions and Direct Support for Realising them}

\section{Inventive user projects}

Finland does not have producer-centred ecosystems that would attract user contributors, yet we could still identify 113 different user inventions or modifications to heat pumps. Most user projects took the relatively cheap Air heat pump (AHP) models as their starting points $(n=77)$, and worked to make them more suited for a cold climate and existing housing stock, but 28 inventions were made also in Ground source heat pump (GSHP) and 8 inventions were made in Exhaust air heat pumps (EAHP). We can cluster these further according to the extent to which the heat 
pump equipment was modified (Botero et al., 2010). At one end we find 20 projects we call user designs, which altered several subsystems of a heat pump or constructed anew some of its subsystems entirely. Twenty-nine alterations were confined within one subsystem of a heat pump and these we call user modifications. Users also created 38 what we call add-on features, which enhanced the heat pumps by adding new parts to them without altering the initial product. There were also eight users that did not alter the make up of their equipment as such, but significantly relocated and repurposed heat pumps or their subsystems in a manner that brought benefits but had not been conceived by the manufacturers. In addition to these, we found various user work-arounds, hacks and rebuildings of heat pumps from different starting configurations.

To give a better sense of these projects let us recount briefly some examples in the category of "user designs". The most common project type was constructing a new kind of heat pump, mostly using an outdoor unit of the Air-to-air heat pump to build up a water heating heat pump (Air-to-water heat pump, AWHP). Apart from the external unit, this entailed a thorough reworking of the technology. There were also new-to-theworld designs, for example, a double source heat pump, which increased efficiency by using ground and air heat source at different outside temperatures. In many cases users sought optimized solutions to meet the requirements of the Nordic climate:

Often various energy sources are combined to provide heating for a house. In one user design case AWHP was used for both space heating and for hot water. In addition, solar thermal collectors were installed to improve energy efficiency. The user built a control logic to automatize the operation of the system. When solar power is not sufficient to heat up the boiler, an AWHP is automatically turned on, and vise versa. Furthermore, in extreme winter conditions, when solar power is not available and the co-efficient of performance (COP) of AWHP becomes low, the control logic turns both renewable sources off, and electricity is used for heating.

Other innovations in this category related to monitoring, sharing data, new coolant gas mixes, new combinations of heat pumps and solar collectors, etc. For a discussion on details of the projects see Hyysalo et al. (2013).

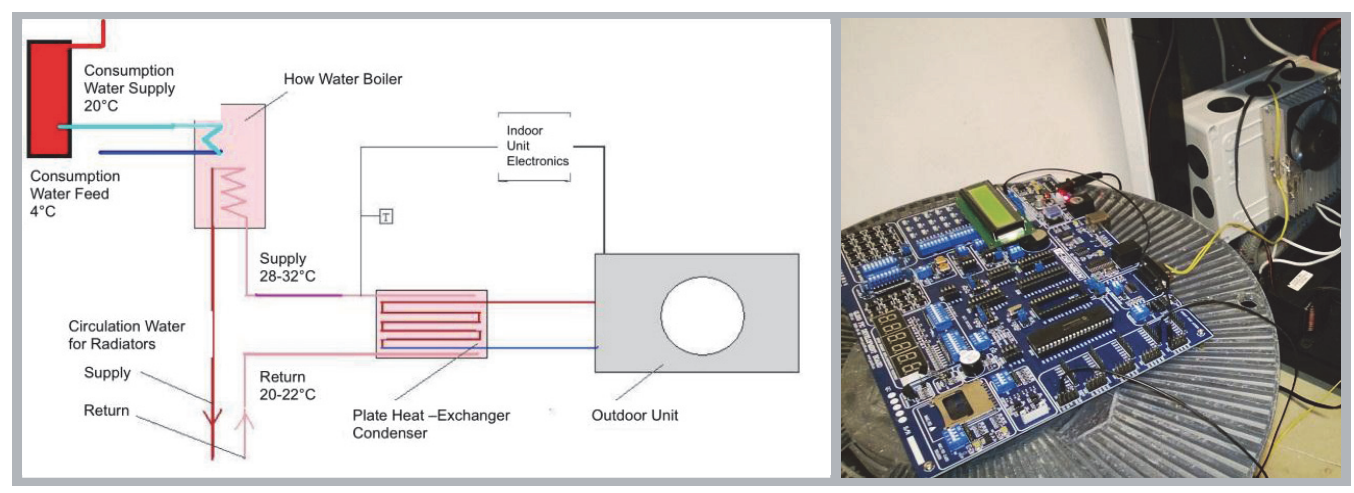

Figure 1. Sketch of DIY air-water heat pump system (left) and photo of an ongoing DIY project (right). (Translated by the authors). 
Immediate peer assistance for inventive user projects

Interviews revealed that all inventive users had some presence in these online environments. These interviews and analysis of the discussion threads indicate that inventive users received various kinds of help from other users, most commonly from 2-5 people. The most common responses to questions or flagged projects expressed different forms of community memory and expertize. This, for instance, indicated that an idea was worth pursuing or, more commonly, that something similar had been tried before or that the idea was unlikely to work or at least not likely to produce the kinds of results expected. Typical questionanswer sequences related to posting an idea of a modification project can be illustrated with the following exchange (Figure 2.):

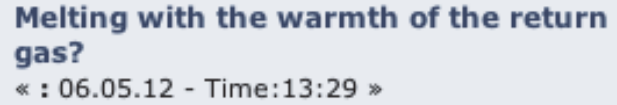

Is it possible to thaw the outdoors unit with the gas that returns from the indoors unit that still has some warmth in it? Put an extra bend onto the top of the outdoors unit bottom plate? Could one thus use after/waste heat of the gas for thaw instead of direct electricity?

Will such hach create problems with thawing, functioning of the device or efficiency or into the defrosting of the lamelles?

Red house and ...

Cellar +2 floors:

4 x Mitsubishi Electric MSZ-FD25VA+MUZ-FD25VABH

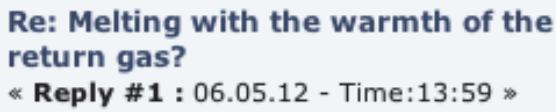

Yes. Apart that its not gas at that point. Or if it is, something is wrong. The only problem you can encounter is that during the defrosting sequence and with reversed circulation the tube can freeze. Even though that doesnôt seem to create problem.

This one did not ice up the whole winter, apart a small bit in the rear end:

\section{$?$ \\ https://picasaweb.google.com/...}

Here is the number one version of AWHP thawing tube:

? https://picasaweb.google.com/...

Version two has that tube raised into the bottom plate, while I turned the water going inside and into the drain. Last winter is through without any need to interfere whatsoever.

Figure 2. The start of an exchange between members at lampopumput.info user forum in 2012. (Translated by the authors). 
The discussion then turns more technical, exploring the conditions and limiting issues that affect this kind of thawing solution. The discussion gives to the project initiator fair opinion on whether his suggested hack can be and has been done, as well as some of the likely issues he may be faced with. Our interviewees regarded these kinds of peer responses to be highly valuable:

\begin{abstract}
The greatest benefit there is that it has experts that really, let us say, know what they are talking about. And towards these specific areas they have [expertise in], you could say, an experts and experimenters attitude. That is what is interesting and useful. On many things you get information that would be very hard to get from elsewhere. (User inventor in AHP)
\end{abstract}

Many user designs attracted further ideas, suggestions for solving problems, and direct iterations of design drawings posted on the forum. However, there was only one open design initiative, where users pooled resources and even this cold air AWHP project appears to end some time after its enthusiastic initiation. Instead, both design and diffusion proceeded sequentially and iteratively.

The users active in DIY threads formed a relatively small group of roughly 300 people that mostly held good technical competence in at least one or two technical areas related to heat pumps. Our interviews brought out, however, a considerable variation within this group in terms of orientation, background, and motivations. Most user inventions were about saving energy through improving the COP of the systems. This is understandable as COP drops dramatically in AHP when outside air get colder, typically turning to the negative somewhere between minus 10 and minus $25^{\circ} \mathrm{C}$ : exactly at the point when the heating need and thus cost is at its peak in the Finnish climate. Whilst this provided an espoused rationale for the activity, our interviews and forum postings indicate that roughly half of the inventive users were strictly "hobbyist", interested in tinkering with their machines. However, among the user inventors were also several researchers working within industry and academia, heat pump professionals such as those working as assemblers and resellers, as well as four users with an entrepreneurial orientation in furthering their business in e.g. home automation.

Gaining control of ones technical equipment, the joy of tinkering, training in or for their profession, and the possibility to stretch the limits of the professional skills, were stressed as reason to engage with selfbuilding activities. Yet, two issues featured in next to all interviews: the importance of forums for learning and in offering "a community of the likeminded" which motivated and justified one's tinkering. These observations parallel those made by (Kuznetsov \& Paulos, 2010) on other Internet communities.

Both the analysis of forum threads and interviews indicate that multiple modes of interaction made possible through the forums, were key in allowing users to turn their diversity into an asset rather than a hindrance. Forums allowed public as well as private postings and responses. The more advanced and more professionally oriented users used private messages as the predominant response medium when it came to more inventive DIY projects. These people stressed the importance of anonymity in both these posting forms, as well as the possibility to then shift to a oneto-one discussion out of forum, to e-mail, or to the phone. Their occupational reputation and commitments would have precluded them from sharing and playing around with re-designing heat pumps in the open. This range of interaction modes also played a major part in referrals of services, materials and tools, which we discuss below - many DIY projects and help given stretched, 
or even violated, permission to access, rules for conduct at some point in their warranty, insurance and professional development.

Table 1. User inventions and immediate peer assistance with them.

\begin{tabular}{|c|c|c|c|c|}
\hline $\begin{array}{l}\text { Forum posts: } \\
\text { DIY }\end{array}$ & \begin{tabular}{|l|} 
Common \\
technological \\
projects
\end{tabular} & Typical thread topics & $\begin{array}{l}\text { Example } \\
\text { contributions offered } \\
\text { by other users }\end{array}$ & $\begin{array}{l}\text { What is provided to } \\
\text { innovative users }\end{array}$ \\
\hline $\begin{array}{l}\text { New user } \\
\text { designs }\end{array}$ & $\begin{array}{l}\text { - AHP to AWHP } \\
\text { - Double source } \\
\text { Ground source \& AHP } \\
\text { - Two phase AWHP } \\
\text { - Pre-heating } \\
\text { incoming air } \\
\text { - Two temp. water } \\
\text { boiler } \\
\text { - Real time COP \& } \\
\text { other sensor displays } \\
\text { / www-feed } \\
\text { - Sun \& AWHP } \\
\text { - New coolant gas } \\
\text { mixes }\end{array}$ & $\begin{array}{l}\text {-Posting an idea or } \\
\text { a project aim for } \\
\text { comments } \\
\text {-Flagging a project } \\
\text { underway } \\
\text {-Reporting a project } \\
\text { progress } \\
\text {-Posting problems } \\
\text { with the project/ } \\
\text { technology } \\
\text {-How to improve } \\
\text { COP? } \\
\text {-How to retain COP in } \\
\text { cold temperature? }\end{array}$ & $\begin{array}{l}\text { - Encouragement, } \\
\text { discouragement, } \\
\text { warnings } \\
\text { - Ideas, experiences } \\
\text { and help } \\
\text { - Iterating design } \\
\text { drawings } \\
\text { - Links to past } \\
\text { projects, problems } \\
\text { and outcomes. }\end{array}$ & $\begin{array}{l}\text { - Learning } \\
\text { environment } \\
\text { - Externalized } \\
\text { memory } \\
\text { - Contacts with } \\
\text { experts on particular } \\
\text { issues } \\
\text { - Fun and problem } \\
\text { solving } \\
\text { - Training in/for } \\
\text { profession } \\
\text { - Gaining control of } \\
\text { ones equipment } \\
\text { - Insight on cost } \\
\text { and eneroy saving }\end{array}$ \\
\hline $\begin{array}{l}\text { User modifi- } \\
\text { cations }\end{array}$ & $\begin{array}{l}\text { - Altering thawing } \\
\text { sequence } \\
\text { - Defrosting } \\
\text { - AHP Outdoor Unit } \\
\text { water removals } \\
\text { - Tweaking } \\
\text { thermostats to get low } \\
8^{\circ} \mathrm{C} \text { indoors } \\
\end{array}$ & & & solutions \\
\hline User add-ons & $\begin{array}{l}\text { - AHP-OU water } \\
\text { channeling } \\
\text { - AHP-OU boxes and } \\
\text { sheds }\end{array}$ & & & \\
\hline $\begin{array}{l}\text { Repurposing } \\
\text { and building }\end{array}$ & $\begin{array}{l}\text { - AWHP from pool } \\
\text { heater } \\
\text { - Exhaust air heat } \\
\text { pump from dryer } \\
\text { - Boiler from oil tank } \\
\text { - AWHP from cooling } \\
\text { machine }\end{array}$ & & & \\
\hline Work-arounds & $\begin{array}{l}\text { - Christmas light to } \\
\text { fool temperature } \\
\text { sensor } \\
\text { - Defrosting sequence } \\
\text { tweaks } \\
\text { - Spraying noise killer } \\
\text { to AHP-internal unit } \\
\text { (IU) }\end{array}$ & & & \\
\hline
\end{tabular}




\begin{tabular}{|c|c|c|c|c|}
\hline $\begin{array}{l}\text { Forum posts: } \\
\text { DIY }\end{array}$ & \begin{tabular}{|l|} 
Common \\
technological \\
projects
\end{tabular} & Typical thread topics & $\begin{array}{l}\text { Example } \\
\text { contributions offered } \\
\text { by other users } \\
\end{array}$ & $\begin{array}{l}\text { What is provided to } \\
\text { innovative users }\end{array}$ \\
\hline Hacks & $\begin{array}{l}\text { - Ripping sensors out } \\
\text { of AHP-IU to optimize } \\
\text { feed } \\
\text { - Disabling "anti- } \\
\text { draft" feature of AHP }\end{array}$ & & & \\
\hline $\begin{array}{l}\text { Re-locating } \\
\text { HP }\end{array}$ & $\begin{array}{l}\text {-AHP-OU to attic } \\
\text { / ceiling / lowered } \\
\text { ceiling } \\
\text { - Heating garages } \\
\end{array}$ & & & \\
\hline $\begin{array}{l}\text { Open design } \\
\text { project }\end{array}$ & - AWHP & $\begin{array}{l}\text { - What to include, } \\
\text { what basic solutions } \\
\text { to build from }\end{array}$ & & \\
\hline
\end{tabular}

In summary, the DIY threads of the forums featured not only trivial tinkering with machines, but a whole range of viable design ideas and realized designs for improving heat pumps. Peers in these sections of the forums provided active help and experience for most heat pump projects. The way they provided this support is, by and large, in line with results on user innovation in products elsewhere (Franke \& Shah, 2003; Jeppesen \& Molin, 2003), apart from the importance of multiple modes of communication and anonymity, which have not been stressed by research on other user innovation communities.

\section{Inadvertent Support for Inventive Users in Internet Forums}

Supporting acquisitions, use and scaling of technology: Enhancing and diversifying the user base

As long as the innovation community equates to the relevant user community, a focus on user inventors' information exchanges may be sufficient (e.g. Jeppesen $\&$ Molin, 2003). But often this is not the case. Often, people are primarily participating in their communities of practice, and innovative activities are a secondary or parasitic concern for most participants (Heiskanen et al., 2010a). Despite its relative indifference towards inventive projects, the larger community can be indispensable to the rise of inventive users. Indeed, in our data set there are a number of community aspects upon which the invention-oriented interchanges build. In the words of one of our informants:

The heat pump forum is a rather conservative site and [it is] not nearly as welcoming and inventive as people in the free-energy forum or pelletforum... [but] e.g. the free-energy forum doesn't give much help for development work for there are too few folks in there. ( $A$ user inventor in AHP and wood pellets)

As we can see, an important set of mechanisms by which user forums support inventive actions by users, is through the attraction of new people and new fixtures to becoming users of heat pump technology. This broad recruitment appears pivotal to gaining critical mass in the competences available. To paraphrase Helgesson and Kjellberg (2009), the forum is a key in fostering the emergence and deepening of usership, the relation between people and the technologies they are engaged in. Let us first examine the emergence part.

The bulk of the 200000 posts in the heat pump forums deal with issues that have most 
relevance to people who are considering whether to buy a heat pump, which model would be most suitable, and how to handle typical problems. The posts are well categorized so as to facilitate comparisons and finding information; general discussion, brand-specific discussions, usage stories in addition to sections directly on acquisition, scaling and ordering of heat pumps. To give an idea of the magnitude of effort (and service) involved, let us briefly recount a calculation posted by one of the users (Figure 3) to aide others in the task of scaling and choosing a heat pump for a newly built house that lacks any energy use history from which to draw upon:

There are several issues in this posting worthy of our attention. It reports a task,

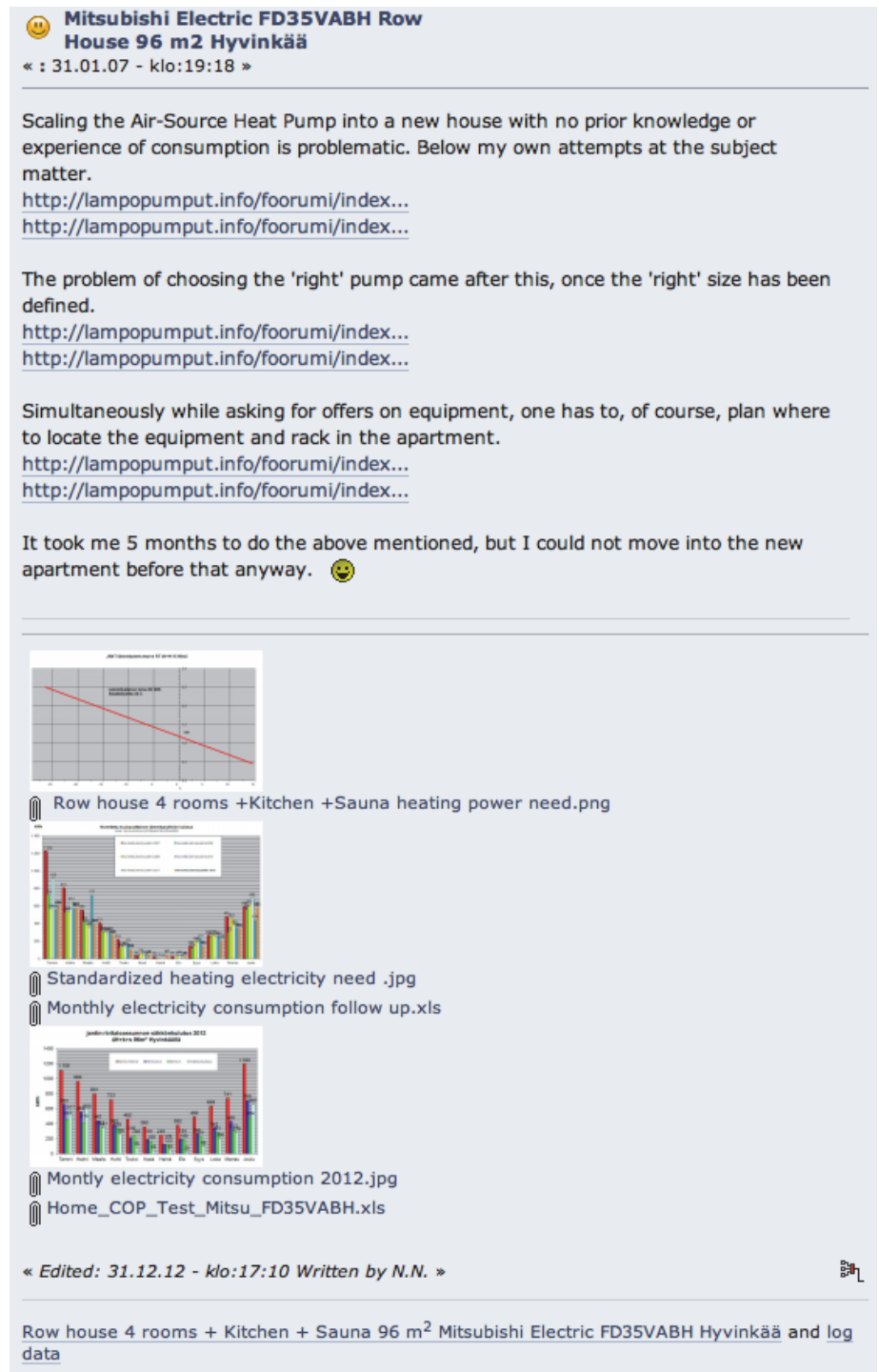

Figure 3. Example of a forum user giving advice for others regarding scaling and selecting a heat pump and finding a location for it. (Translated by the authors). 
scaling and choosing a model, which new users must engage in. One could assume this to be an easy task or at least one easily available from vendors or suppliers, but the post points to the difficulties involved: it took 5 months to do it properly and reliably for a seasoned person. Without it, any supplier or assembler advice would be hard to assess (their numbers potentially having self-serving biases). It also indicates that a one to three hour assessment by a supplier would be a rather rough estimate at best. The uptake of the post, read 60200 times, is a witness to the demand for this type of information and calculation model. Finally, and coming back to usership, the signature of the posting is typical and telling of the forum sociality. Instead of a name or some information about the person (e.g. his interest, education or skill level), there is a description of his house, its location and the heat pump equipment in use. His signature tells what he has done with heat pumps (consumption monitoring, AHP scaling and AHP pictures), in all, it articulates the ingredients that another user would need to qualify and compare with his/ her own. The signature is not information about the "discussant" or "person", but of a specific relationship (between person, equipment and their context) and specific relational sociality (between those engaged or engaging in similar relations), that is, of usership. Indeed, in the whole forum one finds only isolated items that broaden the writer's position beyond that of his technological relationships.

In these relationships, the forum helps make available a range of actors we have elsewhere described as user side intermediaries (Stewart \& Hyysalo, 2008). For instance, the pump-type specific discussion feature peers who are a little more knowledgeable with the technology and can be bothered with questions about technology that may appear silly
- a noted core facet in the uptake of any more complex systems (Sørensen, 2002; Berker et al., 2006). Forums also feature local experts (Stewart, 2007), people who are more knowledgeable than most users and to whom more tricky problems can be addressed. Some of the local experts are just seasoned users, but professional heat pump assemblers, resellers, and dedicated hobbyists also volunteer their advice regularly on the forum, once an issue in a thread becomes flagged as interesting and requiring more serious thought.

A key aspect of these intermediary actions is pointing to non-human mediators by providing pointers to previous threads on the same topic, links to manuals, instruction videos on YouTube, web pages elsewhere, and to COP and other calculators. Whilst most users are quite able to follow instructions, the step towards defining the problem or question is the part where more knowledgeable peers become indispensable. As one of the user inventors reflects:

After all, the forums provide a lot of tips,
already before I acquired [a heat pump]
[I] looked and read much about what
brands would be worth ordering. (User
inventor in AHP)

The scaling of systems with other renewables and non-standard installations are particularly relevant for the inventive user base. Here the help given not only facilitates the rise of a broader user base, but also the emergence of more diversified installations, and on occasions also more diversified background competences of people who, for example, wish to install heat pumps together with wood, pellet, solar, or wind solutions that they are already strongly committed to, or even in which they are professionally expert. These projects create users that must grow quite knowledgeable 
about their systems in order to make them work. Some of our interviewees reported how their competence evolved through grappling with uncatered needs (e.g. keeping a garage at $8^{\circ} \mathrm{C}$ cheaply despite heat pumps supporting only $15^{\circ} \mathrm{C}$ or above) or complex systems (e.g. combinations of heat pumps, wood burning stoves and solar collectors).

Table 2. How heat pump forum supports heat pump acquisition and use.

\begin{tabular}{|c|c|c|c|c|}
\hline $\begin{array}{l}\text { Forum posts: } \\
\text { Community } \\
\text { support }\end{array}$ & $\begin{array}{l}\text { Typical thread } \\
\text { topics }\end{array}$ & $\begin{array}{l}\text { Example solutions } \\
\text { offered by other } \\
\text { users }\end{array}$ & Function for users & $\begin{array}{l}\text { Why it facilitates } \\
\text { user innovation }\end{array}$ \\
\hline $\begin{array}{l}\text { General } \\
\text { Heat Pump } \\
\text { information; } \\
\text { principles, } \\
\text { costs, issues to } \\
\text { consider }\end{array}$ & $\begin{array}{l}\text { - Basic information } \\
\text { about heat pumps } \\
\text { - "Read this first" }\end{array}$ & $\begin{array}{l}\text { - Links to research } \\
\text { papers } \\
\text { - Links to } \\
\text { international forums } \\
\text { - Links to } \\
\text { educational and } \\
\text { training web pages } \\
\text { on HPs }\end{array}$ & $\begin{array}{l}\text { - Basics about } \\
\text { benefits, suitability } \\
\text { and shortcomings } \\
\text { of HPs }\end{array}$ & \multirow[t]{5}{*}{$\begin{array}{l}\text { - Helps expand } \\
\text { community and its } \\
\text { potential diversity }\end{array}$} \\
\hline Acquisitions & $\begin{array}{l}\text { - Which type of heat } \\
\text { pump to select }\end{array}$ & $\begin{array}{l}\text { - ROI calculators, } \\
\text { both self-developed } \\
\text { and links to other } \\
\text { sites }\end{array}$ & $\begin{array}{l}\text { - Lessens } \\
\text { uncertainty }\end{array}$ & \\
\hline $\begin{array}{l}\text { Discussion / } \\
\text { Supporting }\end{array}$ & $\begin{array}{l}\text { - How to sensibly } \\
\text { combine HPs with } \\
\text { solar or wood stoves }\end{array}$ & $\begin{array}{l}\text { - Checking and } \\
\text { updating members } \\
\text { calculations } \\
\text { - Experiences on } \\
\text { how much work } \\
\text { goes in different } \\
\text { alternatives }\end{array}$ & $\begin{array}{l}\text { - Experience and } \\
\text { advice on often } \\
\text { complex choices }\end{array}$ & \\
\hline $\begin{array}{l}\text { Discussion on } \\
\text { the scaling of the } \\
\text { system }\end{array}$ & $\begin{array}{l}\text { - Given house } \\
\text { details: what to do, } \\
\text { what is needed? } \\
\text { - Could a smaller } \\
\text { installation or } \\
\text { combination do? } \\
\text { - Could old heating } \\
\text { system parts be } \\
\text { used? } \\
\text { - Exposing } \\
\text { one's plans and } \\
\text { calculations for } \\
\text { scrutiny }\end{array}$ & $\begin{array}{l}\text { - Suggestions for } \\
\text { alternatives } \\
\text { - Experiences with } \\
\text { analogous homes }\end{array}$ & $\begin{array}{l}\text { - Verifying } \\
\text { calculations } \\
\text { - Sharing experience } \\
\text { - Support for } \\
\text { more complex } \\
\text { combinations } \\
\text { - "Things to } \\
\text { remember" }\end{array}$ & \\
\hline $\begin{array}{l}\text { Discussions on } \\
\text { installation and } \\
\text { usage }\end{array}$ & $\begin{array}{l}\text { - Installation costs / } \\
\text { problems / issues } \\
\text { - Sharing } \\
\text { experiences of usage }\end{array}$ & $\begin{array}{l}\text { - Installation } \\
\text { problem } \\
\text { descriptions and } \\
\text { solving them } \\
\text { - Long follow-ups of } \\
\text { an installation }\end{array}$ & $\begin{array}{l}\text { - Support } \\
\text { installations } \\
\text { - Getting to the } \\
\text { reality of HP heating; } \\
\text { pro-con }\end{array}$ & \\
\hline $\begin{array}{l}\text { Discussion on } \\
\text { specific models }\end{array}$ & $\begin{array}{l}\text { - Problems / } \\
\text { solutions / } \\
\text { experiences with } \\
\text { specific HP model }\end{array}$ & $\begin{array}{l}\text { - Examples of } \\
\text { similar problems/ } \\
\text { behaviours of HP } \\
\text { - Suggestions for } \\
\text { overcoming them }\end{array}$ & $\begin{array}{l}\text {-“Community } \\
\text { knowledge" on } \\
\text { manufacturers and } \\
\text { models } \\
\text { - Counterbalance to } \\
\text { supplier information }\end{array}$ & $\begin{array}{l}\text { - Peer support also } \\
\text { for cheaper and } \\
\text { rarer installations: } \\
\text { helps the growth of } \\
\text { diversity. }\end{array}$ \\
\hline
\end{tabular}


In summary, the most common activities in user-run Internet sustainable energy forums are not primarily or directly related to inventive activities per se. However, acquisitions, scaling, help with problems and help with dealing with suppliers, are topics that draw in thousands of people. This is a critical mass of people, with the potential to answer also DIY-related questions, and is vital for DIY interchanges, not least because it allows timely and competent feedback. We shall next argue that it lays the ground for orientations and actions that are more directly conducive to the effective functioning of a DIY section.

\section{Deepening engagement: Organizing and sharing comparative data}

Several of our interviewees stressed that the forum led them into having a deeper engagement with both the knowledge base, as well as with what can be done with the technology. Let us illustrate this with forum members' comments at different stages of their participation; moving from meeting problems in use, towards DIY projects, and finally to top lead user.
Thanks for clear information. In this area [ground circuit] it feels that when one grasps one thing, you just end up with further questions. (User, GHP forum)

Without this forum I would have faced huge problems with this unit. I doubt that I would have proceeded building this further. It [forum] has been of great help. (An inventing user with AWHP)

I have rather given more to the forum than taken from it, that's the direction"... "I have tried to instruct guys who do this (DIY project), especially in dimensioning so that they get it working and one does not go too far astray. (This user is a semi-professional, and currently creating designs for a small local heat pump manufacturer-reseller)

From the perspective of user inventions, important steps lie between just implementing a heat pump installation and seeing it as natural state of affairs to tinker with these machines. A common

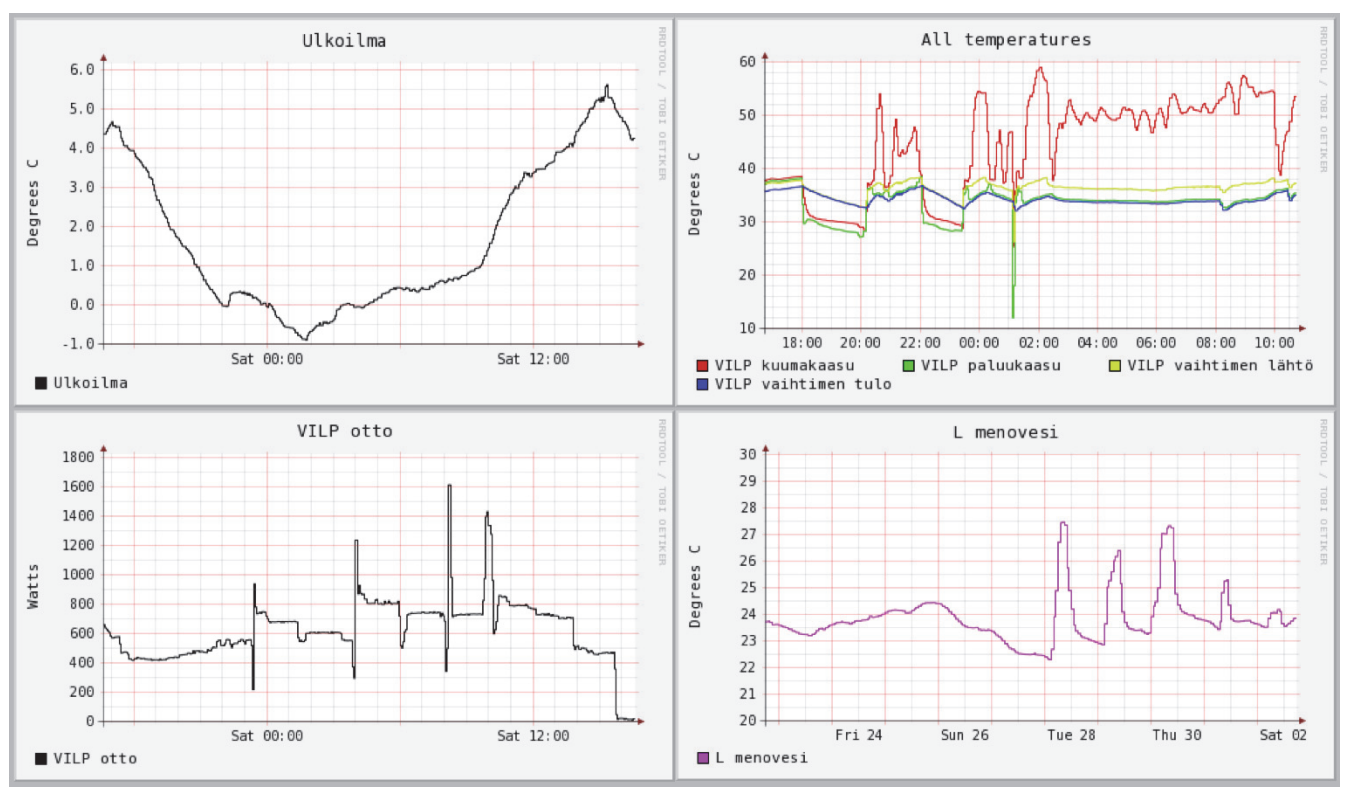

Figure 4. User share heat pump monitoring data graphs via forum and own Internet sites. 
step between these two modes is gathering, organizing and sharing of comparative data. In the forums hundreds of people post or feed automatically their measurements to the forum for comparison and comments or answer polls set by others. Most users are out to verify how their installation compares to others and to factory claims. Some have more general interests in establishing how different HPs factually behave in temperatures that differ from the European standard of $+7^{\circ} \mathrm{C}$. The results tend to show occasions and/or areas where ones installation could be improved and the forums feature active discussions about theoretical matters in HP functioning as well as discussions on trials of changing values and working around sensors. These comparisons also typically involve hacked and redesigned devices, as many hacked systems feature extra sensors and measurement points and are run by enthusiasts - indeed many lead users report having gotten a cheap "toy air heat pump." 
Table 3. Sharing comparative data.

\begin{tabular}{|c|c|c|c|c|}
\hline $\begin{array}{l}\text { Forum post: } \\
\text { Comparison data }\end{array}$ & $\begin{array}{l}\text { Typical thread } \\
\text { topics }\end{array}$ & $\begin{array}{l}\text { Example solutions } \\
\text { offered by other } \\
\text { users }\end{array}$ & Function for users & $\begin{array}{l}\text { Why facilitates } \\
\text { user innovation }\end{array}$ \\
\hline $\begin{array}{l}\text { Real life } \\
\text { comparisons of } \\
\text { different HPs }\end{array}$ & $\begin{array}{l}\text { - Polls to record } \\
\text { COP and other } \\
\text { values in various set } \\
\text { temperatures } \\
\text { - Posting all } \\
\text { one's (daily) } \\
\text { measurements }\end{array}$ & $\begin{array}{l}\text { - Measuring and } \\
\text { entering in their } \\
\text { data } \\
\text {-Links to } \\
\text { measurements } \\
\text { elsewhere }\end{array}$ & $\begin{array}{l}\text {-Comparing real life } \\
\text { and factory values } \\
\text { and different test } \\
\text { temperatures } \\
\text { - Choosing HP } \\
\text { models for use \& } \\
\text { modification }\end{array}$ & $\begin{array}{l}\text { - Points out places } \\
\text { for improvement } \\
\text { - Reference values } \\
\text { for the success of } \\
\text { modifications }\end{array}$ \\
\hline $\begin{array}{l}\text { Real life data of } \\
\text { modified systems }\end{array}$ & $\begin{array}{l}\text { - Posting all one's } \\
\text { measurements as } \\
\text { values, graphs in } \\
\text { packets or real time }\end{array}$ & $\begin{array}{l}\text { - Comments and } \\
\text { approvals } \\
\text { - Explanations why } \\
\text { e.g. COP drops at } \\
\text { certain temperature } \\
\text { - Ideas for further } \\
\text { improvement }\end{array}$ & & $\begin{array}{l}\text { - Establishing the } \\
\text { usefulness of a hack } \\
\text { - Identifying } \\
\text { further points of } \\
\text { improvement }\end{array}$ \\
\hline $\begin{array}{l}\text { Sharing extra } \\
\text { measurements }\end{array}$ & $\begin{array}{l}\text {-Values from extra } \\
\text { sensors added in } \\
\text { HPs (gas temp., } \\
\text { flow speed etc.) } \\
\text { - Real time } \\
\text { measuremet unit } \\
\text { data available }\end{array}$ & $\begin{array}{l}\text { - Comments and } \\
\text { encouragement } \\
\text { - Explanations of } \\
\text { found data } \\
\text { - Iterations for how } \\
\text { to e.g. improve COP }\end{array}$ & $\begin{array}{l}\text { - More thorough } \\
\text { understanding of } \\
\text { how a given HP } \\
\text { factually works }\end{array}$ & $\begin{array}{l}\text { - Detailed reference } \\
\text { data: A view to how } \\
\text { A given HP model } \\
\text { works }\end{array}$ \\
\hline $\begin{array}{l}\text { HP adjustment } \\
\text { and optimization }\end{array}$ & $\begin{array}{l}\text { - Theoretical } \\
\text { discussions } \\
\text { - Trials of changing } \\
\text { values and working } \\
\text { around sensors }\end{array}$ & $\begin{array}{l}\text {-Optimizing } \\
\text { (theory\& practice): } \\
\text { Coolant gas } \\
\text { temperature and } \\
\text { pressure, de- } \\
\text { frosting periods and } \\
\text { running times }\end{array}$ & $\begin{array}{l}\text { - Improving the } \\
\text { COP of their HP }\end{array}$ & $\begin{array}{l}\text { - Theoretical and } \\
\text { practical optimal } \\
\text { values } \\
\text { - Reference values } \\
\text { for the success of } \\
\text { modifications }\end{array}$ \\
\hline
\end{tabular}


To summarize this section, sharing of comparative data appears to be one of the stepping stones to more active engagement with one's energy technology. Sharing and discussing comparisons draw people towards a deeper understanding of and even hacking their equipment. For users who are already inventing or hacking their equipment, monitoring results provide cues for theoretical optimal values and points of reference on how these have been achieved, as well as which models are most suited for uses and hacks that inventive users have in mind.

Getting the means needed: Exchanging parts, tools and services

The reason for most forms of exchanging parts, tools and services has little to do with invention, but is conducive to it nonetheless. The official sales and re-sales marketplace features both working and slightly or wholly malfunctioning machines. It is the latter that offer DIY people access to cheap materials and projects. DIY section exchanges occasionally bypass the marketplace as parts and services are offered and queried alongside advice. Furthermore, joint orders for parts needed in specific modification as well as informal small-scale sales of modified components also take place. From our user interviews we know that further answers and offers are handled by private messaging, but we also found a case where a system was first iterated over several experienced users, and upon final iteration a custom welding was suggested along with a reassurance that "a real coolant man can do the job for you" indicating that (and where) the needed skills and attitude could be found.

There were also common step-by-step (including pictorial) instruction on how to order, install and use specific tools that are useful for DIY work, such as Mango and a PolluCom-energy meter that spread the required hacking skills within the user group. Finally, many DIY projects were documented meticulously picture by picture, and there were also attempts to create lists of useful DIY parts, both actions that are conducive to repeating redesigns by other users (which they did particularly with regard to AWHP designs).

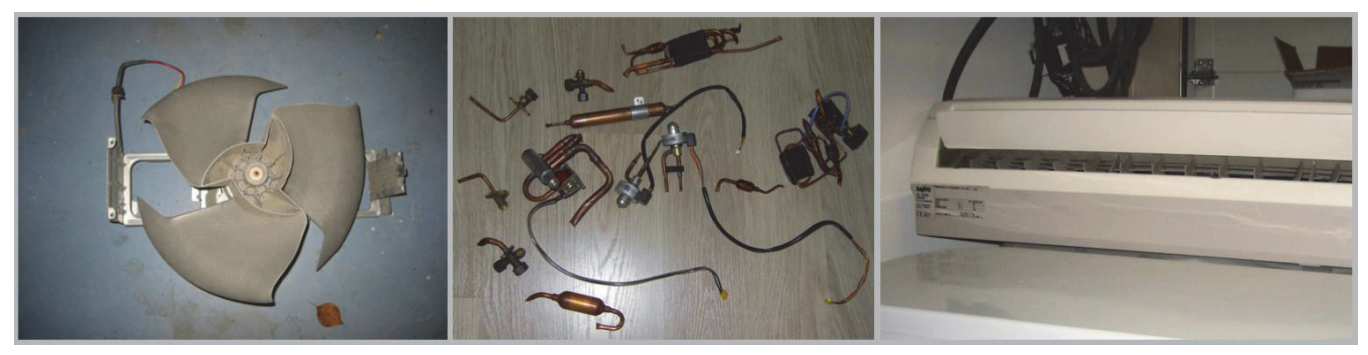

Figure 5. The forum has a market section that provides a wide range of used parts necessary for modifications and new designs. 
Table 4. Forms of parts and service exchange at the forum.

\begin{tabular}{|c|c|c|c|c|}
\hline $\begin{array}{l}\text { Forum posts: } \\
\text { Exchange and } \\
\text { service }\end{array}$ & $\begin{array}{l}\text { Typical thread } \\
\text { topics }\end{array}$ & $\begin{array}{l}\text { Example solutions } \\
\text { offered by other } \\
\text { users }\end{array}$ & Function for users & $\begin{array}{l}\text { Why facilitates } \\
\text { user innovation }\end{array}$ \\
\hline Used HP units & - Sell/Buy & - Sell/buy & $\begin{array}{l}\text { - Second hand } \\
\text { market }\end{array}$ & $\begin{array}{l}\text { - Second hand gear } \\
\text { for modification }\end{array}$ \\
\hline $\begin{array}{l}\text { Parts of HP and } \\
\text { other cooler } \\
\text { systems }\end{array}$ & $\begin{array}{l}\text { - Indications at DIY } \\
\text { section that spare } \\
\text { parts are available } \\
\text { - Queries for } \\
\text { specific parts }\end{array}$ & $\begin{array}{l}\text { - Pointers to where } \\
\text { to get } \mathrm{X} \\
\text { - Offers of } \mathrm{X}\end{array}$ & $\begin{array}{l}\text { - Access to parts } \\
\text { - Getting rid of extra } \\
\text { parts } \\
\text { - Cheap parts }\end{array}$ & $\begin{array}{l}\text { - Cheaper and } \\
\text { easier parts } \\
\text { availability, help } \\
\text { with choosing right } \\
\text { parts }\end{array}$ \\
\hline $\begin{array}{l}\text { Ordering special } \\
\text { parts for DIY }\end{array}$ & $\begin{array}{l}\text { - Ordering DIY } \\
\text { parts from Chinese } \\
\text { manufacturers / } \\
\text { German ebay } \\
\text { - Having a stock of } \\
\text { DIY parts }\end{array}$ & $\begin{array}{l}\text { - Joint orders } \\
\text { - Delivering } \\
\text { modified parts }\end{array}$ & $\begin{array}{l}\text { - Cut shipping costs } \\
\text { - Purchase channels } \\
\text { and skill } \\
\text { - Micro market }\end{array}$ & $\begin{array}{l}\text { - Parts availability } \\
\text {-Motivates DIY } \\
\text { solution sharing }\end{array}$ \\
\hline $\begin{array}{l}\text { Info on assembly } \\
\text { and assemblers } \\
\text { (for DIY) }\end{array}$ & $\begin{array}{l}\text { - Asking for help in } \\
\text { doing some part of } \\
\text { a DIY project } \\
\text { - Asking who could } \\
\text { build a custom } \\
\text { system }\end{array}$ & $\begin{array}{l}\text {-"Why don't you do } \\
\text { it like this drawing } \\
\text {...a real coolant } \\
\text { man can and will } \\
\text { do that hack for } \\
\text { you" }\end{array}$ & $\begin{array}{l}\text { - Expert help } \\
\text { available when } \\
\text { needed }\end{array}$ & $\begin{array}{l}\text { - Sympathetic } \\
\text { expert help } \\
\text { available }\end{array}$ \\
\hline $\begin{array}{l}\text { Instructions on } \\
\text { how to install DIY } \\
\text { tools }\end{array}$ & $\begin{array}{l}\text { - "Installing } \\
\text { Mango..." } \\
\text { - "Using Pollucom } \\
\text { energy meter" }\end{array}$ & $\begin{array}{l}\text { - Step by step } \\
\text { clarifications } \\
\text { - Troubleshooting } \\
\text { and advice }\end{array}$ & $\begin{array}{l}\text { - Getting tools to } \\
\text { function }\end{array}$ & $\begin{array}{l}\text { - Spreads } \\
\text { same tools and } \\
\text { measurements } \\
\text { and competence to } \\
\text { modify and invent }\end{array}$ \\
\hline $\begin{array}{l}\text { Instruction for DIY } \\
\text { design and parts } \\
\text { lists }\end{array}$ & $\begin{array}{l}\text { - Pictorial follow- } \\
\text { ups of HP projects }\end{array}$ & $\begin{array}{l}\text { - Detailed pictures } \\
\text { and explanations } \\
\text { - Linking to } \\
\text { previous designs } \\
\text { - Attempts to make } \\
\text { part list }\end{array}$ & $\begin{array}{l}\text { - Helps to build } \\
\text { own DIY systems } \\
\text { - Making HP } \\
\text { cheaper }\end{array}$ & $\begin{array}{l}\text { - Increases DIY } \\
\text { user base, builds } \\
\text { competence at } \\
\text { DIY, mini-market } \\
\text { for DIY parts and } \\
\text { assembly }\end{array}$ \\
\hline
\end{tabular}


To summarize, the parts and service exchanges provide help and ease with acquiring needed materials and facilitated learning in making particular modifications. Using some of the same parts and DIY tools also spread competence and collaboration to further modify and invent, in effect increasing the user base and the (mini) market for DIY parts and assemblies. We argue that this spread of competences is critical for heat pumps that have a mix of digital, electric, cold gas and plumbing parts. In the following section we turn to connecting the modes of support that forums provide by examining this in terms of the learning they facilitated.

\section{User Forums Facilitating Learning among Diverse People}

To recapitulate, most participants in userrun forums have no explicit intention to invent or facilitate anybody's inventive behaviour, yet they provide indirect support inadvertently by doing what they do. Substantial amounts of discussions, instructions, manuals, photographs, videos, links, calculators et cetera stored in the forum turn it into a shared tool-box and memory repository (Torrey et al., 2007, 2009). Further, it gives access to peers who contribute their insight into defining and solving posted problems, comparisons, voicing shortcomings and taking part in exchange of services and parts. As Watson \& Shove (2008) stress, these resources are crucial ingredients to the emergent nature of competence in the process of doing that is accentuated in DIY activities.

Heat pump users are part of an ecosystem of producers, resellers, importers, regulators, bodies giving professional training etc., as well as peer-to-peer networks such as those found in user forums. This does not, however, make it into an innovation ecosystem per se (Eriksson, 2013). Many, if not most, people engaged in peer-to-peer networks due to a lack of needed information elsewhere in the ecosystem. The forums provided initial help and ideals for one's own actions, and crucially, an environment where one could try, fail and improve with some support and without dire consequences, such as being expelled from the community. This facilitated moving from an apprenticeship position towards increasing mastery. In the words of an interviewee:

Well, when you first buy a device from the store you sort of expect that now you have it. It is not exactly a natural response to open it up and start messing with its internals, losing warranty and spending a fair deal of time. But then you encounter problems and oddities, go to forums and see that others are not so shy about examination of these devices and report fixes and improved energy yields. It becomes more natural to see the product as not so perfect, learn about the topics more. After a while you find that you have implemented a few simple hacks with nothing to it. That would have been simply unfathomable upon first encountering these devices. (User having GHP, AHP and wind power).

Similar deepening community membership was also expressed by other informants:

The joy of writing in a forum is that you can first be pupil and then you can be a teacher (user inventor in AHP).

Such learning trajectories dominate our interviews and fit the ideas of learning as legitimate peripheral participation (Lave \& Wenger, 1991). While this may be a more common facet of Internet forum participation, its prevalence with heat pumps clearly owes much to this 
technology combining several distinct specialist domains: coolant systems, electronics, software, and in many cases also plumbing. All of the interviewed user inventors had started with modifications for which they had background competence: coders built software, electronics engineers hacked sensors, and so on. None had, from the outset, competence to bridge to a more overarching (re)design, but this emerged gradually in the course of their engagement, often in the course of months or even years.

\begin{abstract}
By and large it was about a year that I read [those posts] and then when I started to understand a bit then, then a bit more intensive readings, you see, thermodynamics presents a bit of a tricky equation (user with modifications to GHP).
\end{abstract}

The aspects of the systems that inventive users have come to master and to move beyond their initial competences, include terms and notations (e.g. assembly diagrams different for all technical subsystems), background theories (e.g. coolant gas thermodynamics), skills (e.g. attaching sensors), means (e.g. programming languages), regulations (e.g. what licenses are needed to work with each part of the technology). This knowledge determined what one could do with the technology as well as governed which sections of the forum one is welcomed to participate in and contribute competently to. ${ }^{1}$ The competence emergence in the process of DIY activities stressed by Shove and Watson (2007), can thus be a substantial achievement in some domains, both in terms of it being achieved and the substantial challenge there is in "growing" into an inventive user, as we indicate in section 5.2.

It is noteworthy that the heat pump forums we analysed were conducive to legitimate peripheral participation to far greater an extent than open source development projects, which we have analysed previously (Freeman, 2007). The open source project “OpenOffice.org”, which one of us has followed ethnographically for seven years, features the frequent turn down of volunteers who do not have the required programming skills from the outset; i.e. the project remains open only insofar as one is already competent or close to being competent at the activities in which the community is involved. The heat pump forum's DIY section features some of the same characteristics: excessively incompetent people or overly naïve questions do not receive responses or merely get a referral to a thread elsewhere in the forum. In contrast, however, in the heat pump forum this does not mean a great barrier to entry or learning, as the forum supports myriad other ways to participate other than self-designing. User forums are also more open ended as to what is being done as part of community membership. Most OSS participants are involved in testing and in making small additions to software, whereas user forums are inclusive of also using, sharing, comparing, planning, theorizing, and visioning acts. Furthermore, as noted above, the heat pump forum is comprised of multiple distinct competence areas as well as a range of legitimate roles and orientations. Both are prone to lessen the differences between "in group" and "out group" members. What we hence argue is that while user forums are less organized and less coordinated than OSS projects in their design activities, the former also hold important strengths in fostering the growth of lead user characteristics.

These user-run renewables forums, hence, differ markedly from a clear innovation project or even an innovation community. They also differ somewhat from a clear community of practice, as the forum participants have a wider range of 
orientations, expertise and practices that connect them to the forum. The diversity may be less than in what is typically thought to reside in a boundary infrastructure that is partially shared by several intersecting social worlds (Bowker \& Star, 1999), yet these forums do feature some such diversity. These differences may find their corollary in the outcomes of inventive activities. Instead of joint efforts to build and commercialize new systems, the inventive users have produced a whole array of individual improvements to different heat pump models as well as a range of micro-innovations (Hyysalo, 2009) to make these technologies perform better in their everyday settings.

The learning and inventiveness found in these forums appear to have ties to them being entirely user-run. Those of our interviewees who had been following forums in other countries, stressed that English-speaking forums had, in their assessment, curbed user modifications and critical evaluation due to being moderated by suppliers. Our informants equally stressed the importance of some of the administering solutions taken in lampopumput.info as being conducive to its success. These include light but active moderation, strong segmentation of the forum into manufacturer-specific parts, a DIY section and debate section "hot ring" where moderators move controversial and contested content and hence have to dismiss only contents that are truly libellous or out of scope of the forum. This was seen as favourable to the outcome that multiple specific orientations can exist but do not burden or take over other orientations in the forum.

With these facets, peer-to-peer forums hold a special place with regard to the maintenance, proliferation and further development of these technologies. What becomes elaborated in the forums is not only technologies but also how they are being developed; what can be modified, how producers respond, how regulation responds, how other users embrace novelties and so on. These are keys to having these systems work and proliferate, particularly when it comes to more complex installations that tend to lead to inventive solutions from their users.

\section{Conclusions}

Heat pumps are not the easiest or most likely technology for user invention in renewables, yet the 113 user inventions indicate that users can overcome these hindrances with sufficient peer-to-peer support that is available through user-run Internet forums. These forums play a major role in obtaining help for user projects, the transfer and learning of thematic knowledge, identifying and verifying points of improvement, accessing relevant services, parts and tools, boosting motivation, as well as in the spreading of user inventions among peers.

At the same time, we underscore that these forums' main activities and the main thrust as a novel type of support environment for renewable energy technology, do not reside in these inventions. DIY projects and exchanges between inventive users are a minority phenomenon within the forum activities. The majority of forum activities are centred on scaling, purchasing, maintenance, troubleshooting and comparing of different technology models. They further feature the displaying of monitoring data, parts exchanges, debates and voicing concerns about issues related to these renewables. They act as an informal information infrastructure that, on the whole, acts as central in user side intermediation, offering alternative sources of knowledge and filling information gaps that suppliers, resellers and authorities fail to address. 
Against this backdrop, we argue that the rise of user inventions within the forums owes much to a dynamic that can be captured by a set of concepts we advanced in the course of this article. Inventive users are not "born" but "grow" to have the capacities and special needs/wants that drive them towards invention. In this regard, the user-run Internet forums are conducive to the deepening of usership, and allow some of the other users to act as user side intermediaries to aide this. The learning at stake can be approximated as resulting from legitimate peripheral participation. However, instead of a unified community of practice with a clear centre, these forums span different domains of competence, featuring characteristics of a boundary infrastructure and also facilitating their participants' learning from apprenticeship to mastery across domains of competence.

An implication of this argument is that the study of user innovation would benefit from more careful treatment of the nature of communities and the participations in question. Equating user communities with innovation communities - or drawing a demarcation line between inventive and non-inventive users - masks important differences and areas worth researching.

For instance, whilst both company-run and user-run online forums provide an environment where user modifications are adopted, diffused and iterated further, and where their makers found extra motivation to pursue their activities, the latter unite a range of products and technologies that form a technological whole from the users' perspective (e.g. a set of different renewables configured into heating of a house), whereas a given manufacturer is often limited to one part of the product ecology in question. Just as importantly, the greater diversity and lack of central authority/beneficiary in these user-run forums appears to lead not to a concentrated joint development projects but to a range of individual improvements to many models. Hence, how they contribute to technology development is different.

As to the make up of the forums we examined, they feature several facets relevant to those trying to set up and facilitate technology-related Internet forums: Segmentation of the forum into separate sections to facilitate co-existence of different user orientations, including a separate section for provocative and speculative exchanges; active but tolerant moderation, which primarily refers discussions to appropriate areas, and; allowing private messaging and anonymous presence, which allows different professionals to engage in projects and speculations without reputation loss.

Finally, in terms of policy implications, technology-specific online forums feature several behaviours that Nye et al. (2010) hypothesize as leading to behavioural change among energy consumers (albeit without giving these any empirical backing). Inventive and actively monitoring users set an example to others by deepening engagement with energy technology, arguably leading to higher consciousness of how much energy is consumed and how it has been produced. Easy modifications and add-ons appear to give greater ownership and visibility of energy issues that tend to become "infrastructural" and out of consideration. Most inventive users also provide top end technical assistance to other users that facilitate market creation of these technologies. Hence, whilst their designs can be useful improvements, it may be the competences they create that really matter in terms of energy and climate policy. With regard to facilitating forums themselves, some forums may benefit from nominal support to cover running costs. Companies could also volunteer to further develop best DIY ideas with a compensation scheme in place. Best arrangements in policy, codesign and company involvement are, however, likely to vary with respect to the 
type of forum, technology, and user base in question.

\section{Acknowledgements}

We would like to thank our colleagues in LAICA project for their helpful comments as well as editor Hannu Hänninen and three anonymous reviewers who provided excellent comments to our manuscript. The researchers have received funding for the present work from Academy of Finland grants Local Adaptation and Innovation in Practice in Achieving Carbon Neutrality, (AKA 140933) and User Innovation Pathways to Utility (AKA 138187), as well as Emil Aaltonen Foundation project User Innovation Communities.

\section{Notes}

1 It is worth noting that even if users would have liked to acquire a formal education, there is hardly any single schooling that would prepare anyone to have the encompassing expertise in all the system areas involved here. The professionals, too, have learned many of their skills out in the field.

\section{References}

Baldwin, C., C. Hienerth, E. von Hippel (2006) 'How User Innovations Become Commercial Products: A Theoretical Investigation and Case Study', Research Policy 35: 1291-1313.

Benkler, Y. (2006) The Wealth of Networks: How Social Production Transforms Markets and Freedom (New Haven: Yale University Press).

Berker, T., M. Hartmann \& Y. Punie (2006) Domestication of Media and Technology (Berkshire: McGraw-Hill International).

Bethwaite, F. (2008) Higher Performance Sailing (London: Adlard Coles Nautical).
Blok, Anders (2013) 'Urban green assemblages: An ANT view on sustainable city building projects', Science \& Technology Studies 26(1): XX-XX.

Botero, A., K.-H. Kommonen \& S. Marttila (2010) 'Expanding Design Space: DesignIn-Use Activities and Strategies', in Proceedings of the DRS 2010 (Montreal, Canada): 12.

Bowker, G. \& S.L. Star (1999) Sorting Things Out - Classification and Its Consequences (Cambridge, Mass: MIT Press).

Douthwaite, B., J.D.H. Keatinge \& J.R. Park (2001) 'Why Promising Technologies Fail: The Neglected Role of User Innovation During Adoption', Research Policy 30: 819-836.

Eriksson, K. (2013) 'Innovation and the Vocabulary of Governance', Science \& Technology Studies 26(1): XX-XX.

Fleck, J. (1988) 'Innofusion or Diffusation? The Nature ofTechnologicalDevelopment in Robotics', Edinburgh PICT Working Paper 4 (Edinburgh: United Kingdom).

Flichy, P. (2007) The Internet Imaginaire (MIT Press).

Franke, N., M. Schreier \& U. Kaiser (2010) 'The "I Designed It Myself" Effect in Mass Customization', Management Science 56: 125-140.

Franke, N. \& S. Shah (2003) 'How Communities Support Innovative Activities: An Exploration of Assistance and Sharing Among End-users', Research Policy 32(1): 157-178.

Franke, N. \& E. von Hippel (2003) 'Satisfying Heterogeneous User Needs via Innovation Toolkits: The Case of Apache Security Software', Research Policy 32(7): 1199-1215.

Freeman, S. (2007) 'The Material and Social Dynamics of Motivation', Science Studies 20: 55-77.

Freeman, S. (2011) Constructing a Community - Myths and Realities of the Open Development Model (Helsinki: University of Helsinki): 242. 
Hare, M., N. Gilbert, D. Medugno, J. Heeb \& C. Pahl-Wostl (2001) 'The Development of an Internet Forum for Long-Term Participatory Group Learning About Problems and Solutions to Sustainable Urban Water Supply Management,' in: Sustainability in the Information Society, Presented at the 15th International Symposium Informatics for Environmental Protection (MetropolisVerlag, Marburg):743-750.

Heiskanen, E., S. Hyysalo, T. Kotro \& P. Repo (2010a) 'Constructing Innovative Users and User-Inclusive Innovation Communities,' Technology Analysis \& Strategic Management 22(4): 495-511.

Heiskanen, E., M. Johnson, S. Robinson, E. Vadovics \& M. Saastamoinen (2010b) 'Low-Carbon Communities as a Context for Individual Behavioural Change', Energy Policy, 38(12): 7586-7595.

Helgesson, C.-F. \& H. Kjellberg (2009) 'Practical Use: Enacting the User and that which s Being Used' in: Håkansson, H., A. Waluszewski, F. Prenkert, \& E. Baraldi, (eds), Use of Science and Technology in Business: Exploring the Impact of Using Activity for Systems, Organizations, and People (United Kingdom: Emerald), 241271.

Hienerth, C. (2006) 'The Commercialization of User Innovations: The Development of the Rodeo Kayak Industry,' R\&D Management 36(3): 273-294.

Howe, J. (2009) Crowdsourcing: Why the Power of the Crowd is Driving the Future of Business (New York: Three Rivers Press).

Hyysalo, S. (2009) User innovation and everyday practices: Micro-innovation in sports industry development. $R \& D$ Management 39(3) 247-258.

Hyysalo, S. (2010) Health Technology Development and Use: From Practice Bound Imagination to Evolving Impacts (London: Routledge).
Hyysalo, S., J.K. Juntunen \& S. Freeman (2013) 'User Innovation in Sustainable Home Energy Technologies', Energy Policy 55: 490-500.

Jeppesen, L.B. \& L. Frederiksen (2006) 'Why Do Users Contribute to Firmhosted User Communities? The Case of Computer-controlled Music Instruments', Organization Science 17(1): 45.

Jeppesen, L.B. \& K. Laursen (2009) 'The Role of Lead Users in Knowledge Sharing, Research Policy 38(10): 1582-1589.

Jeppesen, L.B. \& M. Molin (2003) 'Consumers as Co-developers: Learning and Innovation Outside the Firm,' Technology Analysis \& Strategic Management 15(3): 363-383.

Jørgensen, U. \& P. Karnøe (1995) ‘The Danish Wind-Turbine Story: Technical Solutions to Political Visions', in Rip, A., T.J. Misa, J. Schot, (eds), Managing Technology in Society: The Approach of Constructive Technology Assessment (London: Pinter Publishers): 57-82.

Karnøe, P. (1996) 'The Social Process of Competence Building', International Journal of Technology Management 11(7/8): 770-789.

Kuznetsov, S. \& E. Paulos (2010) 'Rise of the Expert Amateur: DIY Projects, Communities, and Cultures', in Proceedings of the 6th Nordic Conference on Human-Computer Interaction: Extending Boundaries (New York: ACM): 295-304.

Lave, J. \&E. Wenger(1991) Situated Learning: Legitimate Peripheral Participation (Cambridge, UK: Cambridge University Press).

Luthje, C. \& E. Von Hippel (2005) 'Userinnovators and "Local" Information: The Case of Mountain Biking,' Research Policy 34(6): 951-965.

Muller, U., I. Eichberger, J. Rummeni, S. Russe, B. Thonon \& R. Nordman (2009) ProHeatPump - Final Results \& Conclusions. 
Nye, M., L. Whitmarsh \& T. Foxon (2010) 'Socio-psychological Perspectives on the Active Roles of Domestic Actors in Transition to a Lower Carbon Electricity Economy', Environment and Planning A 42(3): 697-714.

Ornetzeder, M. \& H. Rohracher (2006) 'User-led Innovations and Participation Processes: Lessons from Sustainable Energy Technologies', Energy Policy 34(2): 138-150.

Pitta, D.A. \& D. Fowler (2005) 'Internet Community Forums: An Untapped Resource for Consumer Marketers', Journal of Consumer Marketing 22(5): 265-274.

Prügl, R. \& M. Schreier (2006) 'Learning from Leading-edge Customers at The Sims: Opening up the Innovation Process Using Toolkits', R\&D Management 36(3): 237-250.

Seyfang, G. (2007) 'Growing Sustainable Consumption Communities: The Case of Local Organic Food Networks', International Journal of Sociology and Social Policy 27(3/4): 120-134.

Sawhney, M., G. Verona \& E. Prandelli (2005) 'Collaborating to Create: The Internet as a Platform for Customer Engagement in Product Innovation', Journal of Interactive Marketing 19(4): 4-17.

Shove, E., M. Watson, M. Hand \& J. Ingram (2007) The Design of Everyday Life (New York: Berg Publishers).

Seyfang, G. \& A. Smith (2007) 'Grassroots Innovations for Sustainable Development: Towards a New Research and Policy Agenda', Environmental Politics 16(4): 584-603.

Sørensen, K.H. (2002) 'Social Shaping on the Move? On the Policy Relevance of the Social Shaping of Technology Perspective', in K.H. Sørensen \& R. Williams (eds), Shaping Technology, Guiding Policy: Concepts, Spaces, and Tools (Cheltenham, UK: Elgar).
Stewart, J. (2007) 'Local Experts in the Domestication of Information and Communication Technologies, Information, Communication \& Society 10(4): 547-569.

Stewart, J. \& S. Hyysalo (2008) 'Intermediaries, Users and Social Learning in Technological Innovation, International Journal of Innovation Management 12(3): 295-325.

Tapscott, D. \& A.D. Williams (2011) Macrowikinomics: New Solutions for a Connected Planet (USA: Penguin Group). Torrey, C., E.F. Churchill \& D.W. McDonald (2009) 'Learning How: The Search for Craft Knowledge on the Internet', in CHI '09 Proceedings of the SIGCHI Conference on Human Factors in Computing Systems (New York: ACM): 1371-1380.

Torrey, C., D. McDonald, B. Schilit \& S. Bly (2007) 'How-To Pages: Informal Systems of Expertise Sharing, in ECSCW 2007 Proceedings of the 10th European Conference on Computer-Supported Cooperative Work (Limerick, Ireland: Springer): 391-410.

von Hippel, E. (2005) Democratizing Innovation (Cambridge Mass: MIT Press).

Watson, M. \& E. Shove (2008) 'Product, Competence, Project and Practice: DIY and the Dynamics of Craft Consumption,' Journal of Consumer Culture 8(1): 69-89.

Weber, S. (2004) The Success of Open Source (Cambridge, Mass: Harvard University Press).

Wenger, E. (1998) Communities of Practice: Learning, Meaning, and Identity (Cambridge, UK: Cambridge University Press).

Williams, R., J.K. Stewart, \& R.S. Slack (2005) Social Learning and Technological Innovation (Cheltenham: Edward Elgar Pub). 
Sampsa Hyysalo

Aalto University School of Business

Management and International Business

Aalto University School of Art

Design and Architecture

Lapuankatu 2, 00100 Helsinki

Finland

sampsa.hyysalo@aalto.fi

Jouni K. Juntunen

Aalto University School of Business

Management and International Business

Lapuankatu 2, 00100 Helsinki

Finland

jouni.juntunen@aalto.fi

Stephanie Freeman

Aalto University School of Business

Management and International Business

Lapuankatu 2, 00100 Helsinki

Finland

stephanie.freeman@aalto.fi

\section{APPENDIX}

\section{Heat pump types and their proliferation in Finland}

A heat pump is a device that diverts heat from one location (the 'source') at a lower temperature to another location ('heat sink') at a higher temperature using mechanical work. The principle, illustrated in the below Diagram 1 is that a working fluid, in its gaseous state, is pressurized and circulated through the system by a compressor (4). On the discharge side (left) of the compressor, the hot and highly pressurized vapor is cooled in a heat exchanger, called a condenser (1), until it condenses into a high pressure, moderate temperature liquid. The condensed refrigerant then passes through a pressure-lowering device (2). The low pressure, liquid refrigerant leaving the expansion device enters another heat exchanger, the evaporator (3), in which the fluid absorbs heat and boils. The refrigerant then returns to the compressor and the cycle is repeated. ${ }^{1}$

In cold climate countries different types of heat pumps have a growing but varied market. Geothermal heat pumps (hereafter GHP) have been in use for over three decades and feature models that have been designed for cold climate. Their uptake, however, has been rather uneven to the extent that Swedish legislative action has spurred over 500000 installations (Muller et al., 2009), whereas Finland features over 70000 units. The upfront investment cost is 15000-30000€.

Air heat pumps (AHP) are built for global mass market, principally in China and Japan, and globally their most used function is cooling, not heating. Those designed for heating are targeted at more moderate climates than the typical Finnish annual range between $30^{\circ} \mathrm{C}$ and $-30^{\circ} \mathrm{C}$ with mean temperature between $3-6^{\circ} \mathrm{C}$. Yet the price of 300-2000€ has attracted consumers and currently 430000 AHPs have been installed in Finland

Air-to-water heat pump (henceforth AWHP) can accommodate a wider temperature range than AHP. Oil burner and water radiators heating structures found in the majority of Finnish detached housing stock encourages fitting an AWHP as it can be assembled alongside or in place of oil heating. AWHP prices range from $7000-12000 €$ and there are around 12000 units in Finland. Finally, exhaust air heat pumps and some other heat pump types also feature in our data, but only as fringe items.

\section{Internet forums of heat pumps}

There are two energy-related Internet forums in Finland specializing in heat pump products. The larger one, a generic heat pump forum, www.lampopumput.info. features over 210000 posts and over 16000

$\overline{1}$ http://en.wikipedia.org/wiki/Heat_pump 


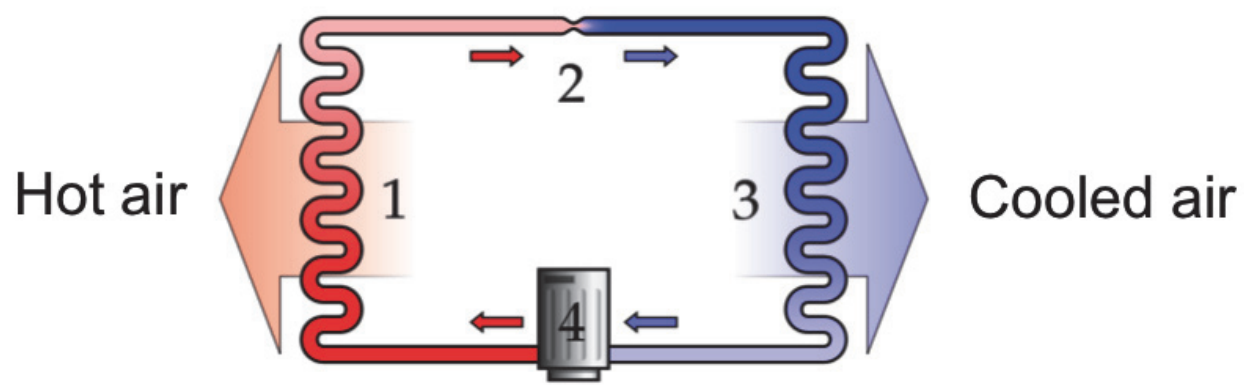

Diagram 1. Heat pump working principle ${ }^{2 .}$

discussion threads by over 4300 discussants in its 7 years of existence. The main forum dedicated to ground source heat pumps, www.maalampofoorumi.fi, features over 49000 posts and over 4300 discussion threads by over 3800 discussants in 8 years of existence.

The forums are maintained on a volunteer basis. Typically, forum administrators are active users of the forums. Administrator users moderate the discussion and are responsible for technical development and maintenance of the site. The forums are used mainly for discussing and finding information about purchase and usage experiences of heat pump products and producers. The discussion is vivid and mostly well-mannered and the moderation principle is inclusive when the discussion topic remains in the area of energy and related technology. In comparison to the forums maintained by commercial vendors, critical writings are allowed and not removed. User inventions are developed further through the help of forums organically, without top down management, which leads to the development of a diverse set of ideas. In manufacturer forums user contributions are directed to help in more focused areas, whereas user-run forums allow multiple orientations.

Both of the studied heat pump forums are structured in a very similar manner, under main categories. They consist of a general discussion, heat pump technical discussions divided in subsections in various ways (e.g. brand names), and sections for purchasing equipment (commercial vendors and users' second hand market).

The forum users are dispersed around Finland and mostly live in detached family house or in row house. Almost all users use pseudonyms. The interviews of lead users revealed some further demographic characteristics of the forum users: $76 \%$ of interviewees had technical education and a majority were middle-aged men. 99\% of ilmalampopumput.info and $96 \%$ of maalampofoorumi.fi registered users are male. In this regard, we use "his" not because of our sexism but because next to all users are male in these heating technology forums. Corresponding extreme gender bias is visible in e.g. knitting forums. The reasons and implications for, for example, forum sociality is a worthy topic of enquiry but not one we pursue in this article. 